\title{
Trends of streamflow, sediment load and their dynamic relation for the catchments in the middle reaches of the Yellow River over the past five decades
}

\author{
Z. L. Gao ${ }^{1,2}$, Y. L. Fu ${ }^{1}$, Y. H. Li ${ }^{1,2}$, J. X. Liu ${ }^{1,2}$, N. Chen ${ }^{1}$, and X. P. Zhang ${ }^{1,2}$ \\ ${ }^{1}$ State Key Laboratory of Soil Erosion and Dryland Farming on the Loess Plateau, Northwest A \& F University, Yangling, \\ Shaanxi 712100, China \\ ${ }^{2}$ Institute of Soil and Water Conservation, Institute of Soil and Water Conservation, CAS \& MWR Yangling, \\ Shaanxi 712100, China
}

Correspondence to: X. P. Zhang (zhangxp@ms.iswc.ac.cn)

Received: 29 March 2012 - Published in Hydrol. Earth Syst. Sci. Discuss.: 24 April 2012

Revised: 30 July 2012 - Accepted: 13 August 2012 - Published: 10 September 2012

\begin{abstract}
To control severe soil erosion on the Loess Plateau, China, a great number of soil conservation measures have been implemented since 1950s and subsequently, the "Grain for Green" project was implemented in 1999. The measures and the project resulted in a large scale land use/cover change (LUCC). Understanding the impacts of the measures and the project on streamflow, sediment load and their dynamic relation is essential because the three elements are closely related to the sustainable catchment management strategy on the Loess Plateau. The data for seven selected catchments in the middle reaches of the Yellow River were used and standardized with the precipitation and the controlling area for analysis. The nonparametric Mann-Kendall test and the Pettitt test were employed to detect trends and change points of the annual streamflow and annual sediment load. Simple linear regressions for the monthly streamflow and sediment load from May to October were made to express their relationship. Based on the change point identification and the time when the project began to be implemented on the Loess Plateau, the complete time for the data records was divided into three periods to compare the change degrees of streamflow, sediment load and their relation for the catchments.

Results show that there are three types of responses in streamflow, sediment load, and their dynamic relations for the seven catchments. The effects of the LUCC on streamflow, sediment load, and their relationships are greatest in the three transition zone catchments followed by the two
\end{abstract}

rocky mountain catchments. The effects are much weaker in the two loess hilly-gully catchments. In general, the change degrees for sediment load are much greater than those for streamflow, which results from the decreased streamflow and weakening trend of their dynamic relation period by period in catchments.

\section{Introduction}

The Loess Plateau of $620000 \mathrm{~km}^{2}$ is located in the middle reaches of the Yellow River $\left(750000 \mathrm{~km}^{2}\right)$. It is characterized with heavily dissected landscape and severe soil loss resulting from wind-deposited loess soils, sparse vegetation, intense rainfall, and a long agricultural history. To control the severe soil erosion, a number of soil conservation measures have been implemented on the Loess Plateau since the 1950s (Ye et al., 1994; Zhang et al., 1998; Ran et al., 2000), which mainly include afforestation, pasture reestablishment, terracing and sediment trapping dams. The measures resulted in great land use and land cover changes (LUCC) and dramatically altered hydrological regimes and significantly reduced sediment load in the Yellow River (Zhu, 1960; Liu and Zhong, 1978; Ran et al., 2000; Zhang et al., 2008; Rustomji et al., 2008). Apart from these, human activities in the last five decades, such as population growth, increasing irrigation areas, reservoirs construction, industry development and coal mining aggravated the water resources crisis on the Loess 
Plateau (Liu and Zhang, 2004; Fu et al., 2004) and simultaneously affected the sediment transport regime (Wang et al., 2007). The climate change has affected the Yellow River basin with the noted increase in minimum temperature and no appreciable change in precipitation in the last $50 \mathrm{yr}(\mathrm{Fu}$ et al., 2004). Although the sensitivity of streamflow to precipitation, temperature or potential evaportranspiration was detected (Fu et al., 2007; Zheng et al., 2009), human activities were believed to be the primary driving force behind the trends of streamflow and sediment load in the catchments and the main stream of the Yellow River basin (Ran et al., 2000; Liu and Zhang, 2004; Fu et al., 2004, 2007; Li et al., 2004; Wang et al., 2007; Zheng et al., 2009; Zhang et al., 2008; Rustomji et al., 2008; Gao et al., 2011).

It is well known that afforestation and biophysical measures can alter catchment's water balance by increasing rainfall reception and evapotranspiration (Zhang et al., 2001; Brown et al., 2005). Soil erosion and sediment transport are therefore decreased through decreasing surface runoff and increasing water infiltration into the soil (Colman, 1953; Morgan, 1986; Sahin and Hall, 1996; Castillo et al., 1997; Quinton et al., 1997). Huang and Zhang (2004), Mu et al. (2007), and Zhang et al. (2008) found that changes in streamflow tended to be relatively uniform across the flow spectrum with typical reductions of 30-60\% in catchments in the region due to soil conservation measures. Since the 1980s, a great amount of research has been conducted and the results showed that sediment load in the catchments on the Loess Plateau tended to manifest a significantly negative trend and sediment retention benefit was estimated with soil and water conservation measures (Chen et al., 1988; Tang, 1993; Wang and Wu, 1993; Ye, 1994; Yu, 1997; Zhang et al., 1998; Ran et al., 2000; Wang and Fan, 2002; Yao et al., 2005, 2010). Runoff-sediment behaviors are also believed to change because of the mechanisms of afforestation and check dams. In general the change of sediment yield from a catchment was expected resulting from one or both variables of suspended sediment concentration and discharge. Some researches were conducted to check the change of sediment concentration in catchments. Xu (2002) and Liao et al. (2008) showed that the frequency of hyperconcentration flow, the main form of sediment transportation on the Loess Plateau, was decreased due to the implementation of soil conservation measures in the region. Rustomji et al. (2008) showed that mean annual sediment concentration in 7 of 11 catchments exhibited a statistically significant decreasing trend over time. A few researches focused on the relationship between streamflow and sediment load. However, the results were inconsistent and complex. Zheng and Cai (2007) concluded that increasing vegetation coverage didn't change the relationship between streamflow and sediment load in the paired catchments. However, an opposite conclusion was drawn from Liu et al. (2010), who showed that the relationship between streamflow and sediment load obviously changed with land use change in other paired catchments under heavy rainfall and high rainfall intensity. Rustomji et al. (2008) showed that although the results from the sediment rating curves, based on the daily data, support the conclusion of the variations of annual suspended sediment concentration, the soil conservation measures seemly did not significantly change the sediment rating curves in two years with similar precipitation in two catchments on the Loess Plateau. Pan et al. (1999) indicated that the relationship between streamflow and sediment load in the flood season did not essentially change in a region with area of $11 \times 10^{4} \mathrm{~km}^{2}$ on the Loess Plateau.

The above research indicates that LUCC resulting from soil conservation measures can affect hydrological regimes and in turn, sediment transport processes in a catchment. But it is not very clear how the soil conservation measures affect the relationships between streamflow and sediment load in a catchment. The inconsistent results are probably due to the data used, specific landform of the studied area, age and type of vegetation, soil characteristics, rainfall intensity, spatial scale focused on, and mixed nature of historic soil conservation measures. Obviously further research is needed in this field. Furthermore, the "Grain for Green" project has been widely implemented since 1999. It is very important to fully understand the impacts of soil conservation measures and vegetation restoration on streamflow, sediment load, and runoff-sediment behaviors in the region to provide an integrated estimate for the effects of soil conservation measures on hydrology and sediment transportation and help ecological management in the catchments on the Loess Plateau. Therefore, the specific objectives of this study were to (1) examine the trends and change points of annual streamflow and annual sediment load over the last $50 \mathrm{yr}$ in seven selected catchments on the Loess Plateau; (2) find the changes in the streamflow and sediment load represented by monthly flow/ sediment duration curves; and (3) investigate the changes in the dynamic relation of streamflow to sediment load in different periods in the catchments.

\section{Study area}

The coarse sand hilly catchments (CSHC) with a total area of $1.13 \times 10^{5} \mathrm{~km}^{2}$, on the Loess Plateau, are recognized as the main source of coarse sediment $(>0.1 \mathrm{~mm}$ ) on a downstream bed (Fig. 1). Average annual precipitation in the CSHC is $456 \mathrm{~mm}$, varying from more than $600 \mathrm{~mm}$ in the southeast to less than $300 \mathrm{~mm}$ in the northwest. About $78 \%$ of annual precipitation occurs from May to October. The northwestern part of the CSHC is considerably flat and the southeastern part is characterized by a heavily dissected landscape with gully densities ranging from 2 to $8 \mathrm{~km} \mathrm{~km}^{-2}$ (Chen et al., 1988; McVicar et al., 2007). The wind-deposited loess soils, developed during Quaternary Period, cover the study area with a thickness of 50-200 m. Coarse sandy soils are common in the northwest and finer clay-rich soils occur in the southeast. 


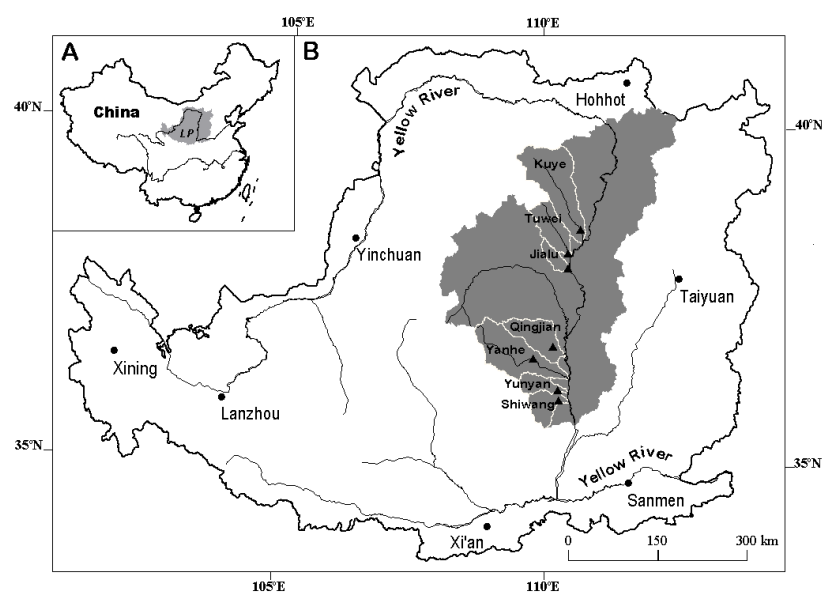

Fig. 1. (A) location of the Loess Plateau (grey shading) in the middle reaches of the Yellow River, China. (B) location of the CSHC (grey shading) on the Loess Plateau and study catchments (marked by their names and delineated by the white lines). The triangles indicate the hydrological gauge stations in the catchments.

In total, seven catchments within the CSHC were selected for the purpose of study, and details of which are given in Table 1. Three catchments are located in the transition zone from the flat sandy area in northwest to the hilly-gully area in the middle of the CSHC. Two catchments are in the loess hilly-gully area and the other two, in the rocky mountain area in the south. Pasture is the dominant vegetation type in the three transition zone catchments and forest dominates the two rocky mountain catchments. In the two loess hilly-gully catchments, the vegetation type is characterized with transitional features from forest to steppe.

The areas for historic soil conservation measures in the seven catchments are given in Table 2, which were obtained through census (Ran et al., 2000). The areas of terraces, afforestation, pasture land, and sediment-trapping dams all increased from 1959 to 1996 . The increased rates were the greatest in the 1970s and 1980s. The vegetation coverage, represented by NDVI, was found to have an increasing trend at $P<0.05$ significance level on the Loess Plateau in the last $20 \mathrm{yr}$ due to the "Grain for Green" project implementation (Xin et al., 2007; Sun et al., 2012).

\section{Data and methods}

\subsection{Data description}

Monthly streamflow and sediment load data in the seven catchments were obtained from the Water Resources Committee of the Yellow River Conservancy Commission of China (Table 1). Monthly precipitation data were obtained from the State Meteorology Bureau of China. Monthly precipitation data are spatially interpolated using the ordinary Kriging method (Wan et al., 2011). The area-weighted method is used to compute the monthly precipitation in each catchment. Monthly streamflow, sediment load and precipitation data are then accumulated to annual totals. To reduce the effects of precipitation and drainage area on the analysis of streamflow and sediment load for the catchments of different size, the volumes of annual/monthly streamflow and sediment load are standardized by controlling area and precipitation in corresponding time. So a unit for streamflow is " $\mathrm{m}^{3} \mathrm{~km}^{-2} \mathrm{~mm}^{-1}$ ", which is dimensionless; the value is 1000 times the runoff coefficient and signifies that the runoff availability $\left(\mathrm{m}^{3}\right)$ per $\mathrm{km}^{2}$ area per $\mathrm{mm}$ precipitation in a catchment in a given period. A unit for sediment load, " $\mathrm{km}^{-2} \mathrm{~mm}^{-1}$ ", actually signifies sediment availability ( $\mathrm{t}$ ) per $\mathrm{km}^{2}$ area per $\mathrm{mm}$ precipitation in a catchment in a given period.

\subsection{Trend test and change point analysis}

\subsubsection{Mann-Kendall test and Pettitt test}

The nonparametric Mann-Kendall method proposed by Mann (1945) and improved by Kendall (1975) is widely used to test trends in hydrological and climatological time series, mainly because it is simple, robust, and can handle the values missed or below the detection limits (Xu et al., 2005; Bi et al., 2009). The method has been recommended by the World Meteorological Organization (1988) as a standard procedure for detecting trends in hydrological data that are serially independent (Hamed and Rao, 1998).

In the Mann-Kendall test, the null hypothesis, $H_{0}$, is that the observations, $x_{i}(i=1,2, \ldots, j, k, \ldots, n)$, are independent and identically distributed. The alternative hypothesis, $H_{1}$, is that a monotonic trend exists in $x_{i}$. The Mann-Kendall test statistic, $S$, is calculated using the the formula:

$$
\begin{aligned}
& S=\sum_{j=1}^{n-1} \sum_{k=j+1}^{n} \operatorname{sgn}\left(x_{k}-x_{j}\right) \\
& \operatorname{sgn}\left(x_{k}-x_{j}\right)=\left\{\begin{array}{l}
1 x_{k}-x_{j}>0 \\
0 x_{k}-x_{j}=0 \\
-1 x_{k}-x_{j}<0
\end{array}\right.
\end{aligned}
$$

where $n$ is the number of observed data series, and $x_{j}$ and $x_{k}$ are the values in periods $j$ and $k(j<k)$, respectively. For $n \geq 10$, the statistic, $S$, is approximately normally distributed with the mean and variance:

$$
\begin{aligned}
& E(S)=0 \\
& \operatorname{VAR}(S)=\frac{1}{18}\left[n(n-1)(2 n+5)-\sum_{p=1}^{q} t_{p}\left(t_{p}-1\right)\left(2 t_{p}+5\right)\right]
\end{aligned}
$$

where $q$ is the number of tied groups and $t_{p}$ is the number of data values in the $p$ th group. 
Table 1. Description of the seven catchments in the middle reaches of Yellow River, China.

\begin{tabular}{lrrrrrll}
\hline Catchment & $\begin{array}{r}\text { Controlling } \\
\text { area }\left(\mathrm{km}^{2}\right)\end{array}$ & $\begin{array}{r}\text { Mean annual } \\
\text { precipitation } \\
(\mathrm{mm})\end{array}$ & $\begin{array}{r}\text { Mean annual } \\
\text { streamflow } \\
\left(10^{8} \mathrm{~m}^{3}\right)\end{array}$ & $\begin{array}{r}\text { Mean annual } \\
\text { sediment load } \\
\left(10^{8} \mathrm{t}\right)\end{array}$ & $\begin{array}{r}\text { Vegetation } \\
\text { coverage }(\%)\end{array}$ & $\begin{array}{l}\text { Datum } \\
\text { records }\end{array}$ & $\begin{array}{l}\text { Landform } \\
\text { feature }\end{array}$ \\
\hline Kuye & 8645 & 384.6 & 5.8 & 0.91 & 6.5 & $1956-2005$ & Transition zone from \\
Tuwei & 3253 & 403.0 & 3.4 & 0.18 & 9.8 & $1956-2005$ & $\begin{array}{l}\text { sandy area to loess } \\
\text { hilly-gully area }\end{array}$ \\
Jialu* & 1121 & 412.0 & 0.6 & 0.13 & 3.3 & $1957-2005$ & hily \\
\hline Qingjian & 3468 & 477.7 & 1.4 & 0.40 & 3.6 & $1955-2005$ & Loess \\
Yanhe & 5891 & 514.0 & 2.1 & 0.46 & 9.2 & $1956-2005$ & hilly-gully area \\
\hline Yunyan & 1662 & 541.0 & 0.3 & 0.03 & 54.7 & $1966-2005$ & Rocky mountain \\
Shiwang & 2141 & 561.0 & 0.7 & 0.02 & 66.5 & $1959-2005$ & area \\
\hline
\end{tabular}

* Without the data of 1968 .

The standard test statistic, $Z$, is computed as follows:

$Z= \begin{cases}\frac{S-1}{\sqrt{\operatorname{VAR}(S)}} & \text { if } S>0 \\ 0 & \text { if } S=0 \\ \frac{S+1}{\sqrt{\operatorname{VAR}(S)}} & \text { if } S<0 .\end{cases}$

The statistic, $Z$, follows the standard normal distribution. If $|Z| \geq Z_{1-\alpha / 2}, H_{0}$ is rejected and a significant trend exists in the observed time series. A positive value of $Z$ indicates an upward trend and a negative value of $Z$, a downward trend.

Trend magnitude is estimated using a nonparametric median based slope method proposed by Sen (1968) and extended by Hirsch et al. (1982):

$\beta=\operatorname{Median}\left[\frac{X_{k}-X_{j}}{k-j}\right]$ for all $j<k$.

where $1<j<k<n$. $\beta$ is the median of all possible combinations of pairs for the whole data set.

The nonparametric Pettitt test is used in this study to detect a change point if a significant trend existed in the data series. The test is a kind of distribution-free method and allows minimum assumptions to be made about the data (Pettitt, 1979). Therefore, it is particularly suited to the hydrological series. The test is robust, simple and relatively powerful (Kundzewicz and Robson, 2004). The Pettitt test uses a version of the Mann-Whitney statistic, $U_{t, N}$, that verifies if two samples of $x_{1}, \ldots, x_{t}$ and $x_{t+1}, \ldots X_{N}$ are from the same population. The test statistic, $U_{t, N}$, is given by

$U_{t, N}=U_{t-1, N}+\sum_{j=1}^{N} \operatorname{sgn}\left(x_{t}-x_{j}\right)$ for $t=2, \ldots N$

where $\operatorname{sgn}(\theta)=1$ if $\theta>0 ; \operatorname{sgn}(\theta)=0$ if $\theta=0 ; \operatorname{sgn}(\theta)=-1$ if $\theta<0$.

The test statistic counts the number of times a member of the first sample exceeds a member of the second sample. Its statistic $k(t)$ and the associated probabilities used in the significance testing are

$k(t)=\max _{1 \leq t \leq N}\left|U_{t, N}\right|$ and

$P \cong 2 \exp \left\{-6\left(k_{N}\right)^{2} /\left(N^{3}+N^{2}\right)\right\}$.

Additionally, sequential Mann-Kendall test is also used to validate the result of change point detected with Pettitt test in the time series of streamflow and sediment load. It is also helpful to compare the results of change point tested by the non-parametric methods with the original data series to determine the change point used in this study.

\subsubsection{Serial correlation test}

Serial correlation has the effect on Mann-Kendall test. The existence of positive autocorrelation in data increases the probability of detecting trends when actually none exists (Partal and Kahya, 2006). Thus, the time series should be "pre-whitened" to eliminate the effect of serial correlation before applying Mann-Kendall test. The lag 1 serial correlation coefficient, $r_{1}$, is calculated to detect the autocorrelation of the data used in the study. The lag- 1 autocorrelation is the correlation between $x_{i}$ and $x_{i+1}$. It has the formula:

$r_{1}=\frac{\sum_{i=1}^{N-1}\left(x_{i}-\bar{x}\right)\left(x_{i+1}-\bar{x}\right)}{\sum_{i=1}^{N}\left(x_{i}-\bar{x}\right)^{2}}$

where $N$ is the length of the time series, $x_{i}$ is the value of the time series at time $t$, and $\bar{x}$ is the overall mean of $x_{i}$.

The significance of $r_{1}$ can be estimated using the one-tail $95 \%$ significance of the Guassian distribution:

$r_{k}(95 \%)=\frac{-1 \pm 1.96 \sqrt{N-k-1}}{N-k}$

where $k$ is the time lag and $r_{k}$ is the autocorrelation coefficients at the time lag of $k$.

The critical values of the calculated lag- 1 serial correlation coefficient, $r_{1}$, at the $5 \%$ significance level are -0.288 and 
Table 2. Cumulative area of soil conservation measures for each of catchments from 1950 s to $1990 \mathrm{~s}^{\mathrm{a}}$.

\begin{tabular}{|c|c|c|c|c|c|c|}
\hline Catchment & Year & $\begin{array}{l}\text { Terrace } \\
\left(\mathrm{km}^{2}\right)\end{array}$ & $\begin{array}{l}\text { Afforestation } \\
\left(\mathrm{km}^{2}\right)\end{array}$ & $\begin{array}{l}\text { Pasture } \\
\left(\mathrm{km}^{2}\right)\end{array}$ & $\begin{array}{l}\text { Sediment } \\
\text { trapping } \\
\text { damb }^{\mathrm{b}} \\
\left(\mathrm{km}^{2}\right)\end{array}$ & $\begin{array}{l}\text { Area } \\
\text { affected } \\
(\%)\end{array}$ \\
\hline \multirow[t]{5}{*}{ Kuye } & 1959 & 4.5 & 26.8 & 22.3 & 0.3 & 0.6 \\
\hline & 1969 & 32.9 & 97.3 & 51.5 & 2.4 & 2.1 \\
\hline & 1979 & 65.6 & 415.0 & 109.9 & 7.5 & 6.9 \\
\hline & 1989 & 67.0 & 1004.3 & 353.1 & 12.1 & 16.6 \\
\hline & 1996 & 99.1 & 1184.2 & 379.8 & 19.1 & 19.5 \\
\hline \multirow[t]{5}{*}{ Tuwei } & 1959 & 1.0 & 25.4 & 1.4 & 0.2 & 0.9 \\
\hline & 1969 & 10.8 & 77.7 & 6.1 & 1.7 & 2.9 \\
\hline & 1979 & 31.3 & 174.7 & 16.1 & 7.1 & 7.0 \\
\hline & 1989 & 45.5 & 754.5 & 28.8 & 11.1 & 25.8 \\
\hline & 1996 & 66.5 & 1021.6 & 37.4 & 15.5 & 35.1 \\
\hline \multirow[t]{5}{*}{ Jialu } & 1959 & 4.3 & 9.2 & 2.3 & 0.8 & 1.5 \\
\hline & 1969 & 27.3 & 41.7 & 1.7 & 4.1 & 6.7 \\
\hline & 1979 & 67.1 & 97.5 & 10.2 & 9.7 & 16.5 \\
\hline & 1989 & 104.3 & 293.9 & 12.8 & 12.9 & 37.8 \\
\hline & 1996 & 141.4 & 295.3 & 15.5 & 16.3 & 41.8 \\
\hline \multirow[t]{5}{*}{ Qingjian } & 1959 & 6.9 & 13.1 & 0.2 & 1.7 & 0.6 \\
\hline & 1969 & 41.9 & 46.8 & 2.8 & 11.0 & 3.0 \\
\hline & 1979 & 92.9 & 110.9 & 6.1 & 31.7 & 7.0 \\
\hline & 1989 & 145.6 & 596.5 & 25.7 & 46.5 & 23.5 \\
\hline & 1996 & 161.6 & 652.9 & 27.3 & 46.6 & 25.6 \\
\hline \multirow[t]{5}{*}{ Yanhe } & 1959 & 4.1 & 41.3 & 0.3 & 4.6 & 0.9 \\
\hline & 1969 & 47.2 & 161.3 & 3.7 & 15.8 & 3.9 \\
\hline & 1979 & 97.5 & 286.9 & 17.5 & 28.7 & 7.3 \\
\hline & 1989 & 174.3 & 840.7 & 145.2 & 37.8 & 20.3 \\
\hline & 1996 & 275.6 & 1100.2 & 259.9 & 41.7 & 28.5 \\
\hline \multirow[t]{5}{*}{ Yunyan } & 1959 & 0.9 & 9.2 & 0.1 & 0.5 & 0.6 \\
\hline & 1969 & 13.7 & 33.3 & 0.3 & 2.0 & 3.0 \\
\hline & 1979 & 29.1 & 78.0 & 2.0 & 3.1 & 6.7 \\
\hline & 1989 & 56.0 & 245.6 & 25.3 & 4.0 & 19.9 \\
\hline & 1996 & 83.7 & 371.9 & 51.4 & 4.7 & 30.8 \\
\hline \multirow[t]{5}{*}{ Shiwang } & 1959 & 4.6 & 1.2 & 0.6 & 0.1 & 0.3 \\
\hline & 1969 & 16.9 & 30.7 & 1.6 & 0.5 & 2.3 \\
\hline & 1979 & 38.7 & 67.9 & 3.0 & 1.0 & 5.2 \\
\hline & 1989 & 59.1 & 150.7 & 10.5 & 1.1 & 10.3 \\
\hline & 1996 & 73.8 & 233.1 & 12.8 & 1.6 & 15.0 \\
\hline
\end{tabular}

${ }^{a}$ Referred to Ran et al. (2000). ${ }^{\mathrm{b}}$ This column represents the impounded surface area of sediment-trapping dams when full.

0.249. Thus, if $r_{1}$ is out of the interval, the lag-1 autocorrelation is statistically significant. If $r_{1}$, is not significant at the $5 \%$ level, the Mann-Kendall test is applied to original values of the time series. Few series (less than $5 \%$ ) in the data set used in the study appear to have a significant lag-1 serial correlation coefficient. Therefore, the Mann-Kendall test is applied to test the trends of the time series in our study.

\section{Results and discussion}

\subsection{Trends, change points and relative changes for annual streamflow}

Annual streamflow (with unit of $\mathrm{m}^{3} \mathrm{~km}^{-2} \mathrm{~mm}^{-1}$ ) in the five catchments except the two loess hilly-gully catchments presented negative trends by the Mann-Kendall test with statistically significance level, in which four catchments were detected at $p<0.001$ and one at $p<0.05$ (Fig. 2, Table 3). The 

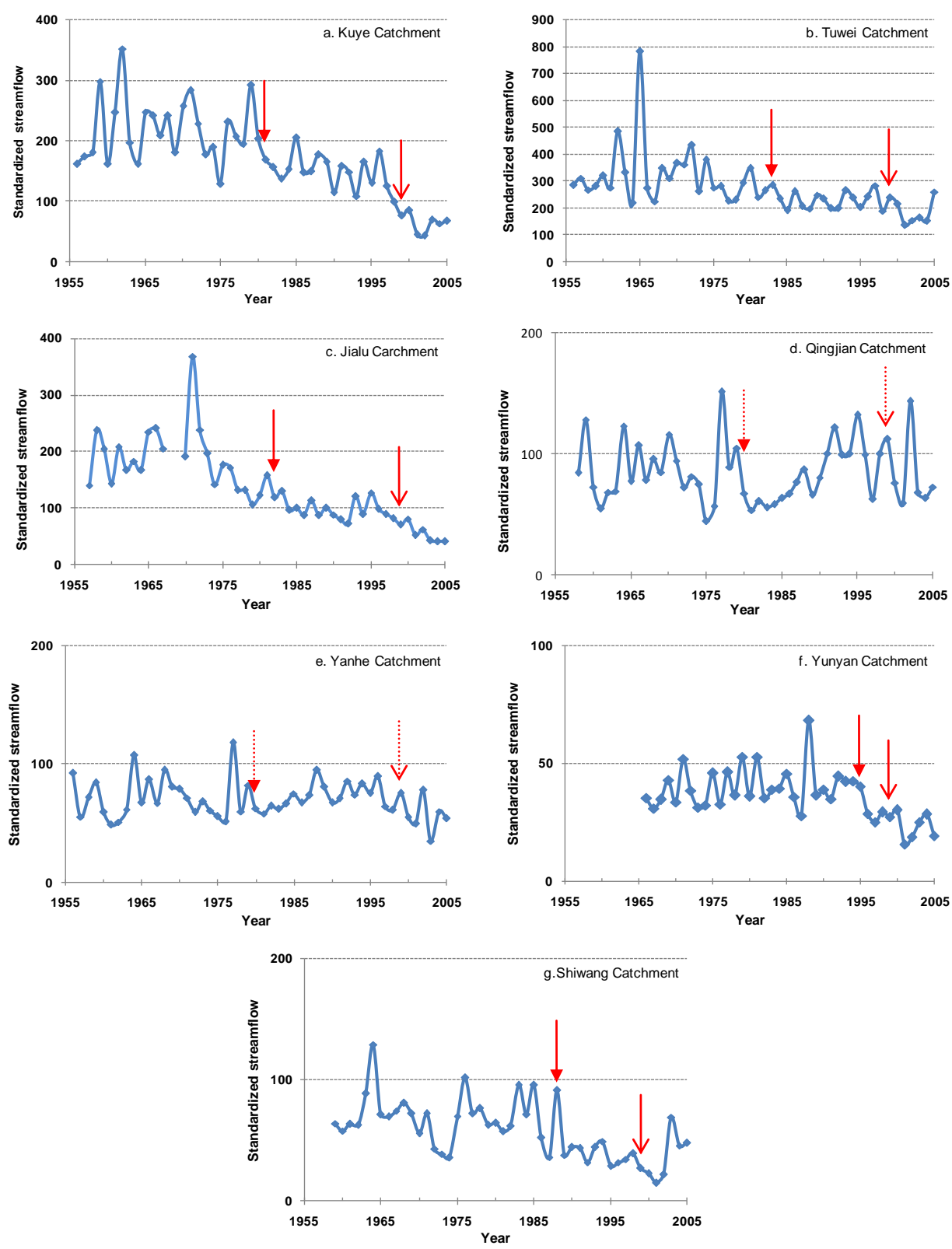

Fig. 2. Standardized annual streamflow with unit $\mathrm{m}^{3} \mathrm{~km}^{-2} \mathrm{~mm}^{-1}$ in seven catchments. Change points detected with the Pettitt test were marked with 1st solid red arrow in plots (a), (b) and (c), three transition zone catchments, and plot (f) and (g), two rocky mountain catchments. The 2 nd red arrow in plots $(\mathbf{a}-\mathbf{c})$ and $(\mathbf{f}-\mathbf{g})$ signify the year 1999. Change points were given in plot (d) and (e), two loess hilly gully catchments, see Table 3.

average change rate of annual streamflow was -3.39 per year in the three transition zone catchments, but only -0.67 per year in the two rocky mountain catchments. Average change rate for the former was about 5 times that for the latter. However, the two loess hilly-gully catchments, i.e., Qingjian and Yanhe catchments, were an exception. The change rate of the annual streamflow in Qingjian catchment manifested a slightly increasing trend, but in the Yanhe catchment, a slightly decreasing trend, both of which were statistically insignificant.
The change points detected by the Pettitt test and the sequential Mann-Kendall test for annual streamflow in the five catchments were, in general, highly consistent and had a statistically significant level. To the difference of change point tested by two methods in the Kuyehe River, the result detected by the Pettitt test was considered to be rational as compared with the original data series (Fig. 2 and Table 3). The change points for the Kuye, Jialu, and Tuwei catchments in the transition zone occurred in 1981, 1982 and 1983 and for the Yunyan, Shiwang catchments in the rocky mountain area 
Table 3. Trends of the annual streamflow and change points by the Mann-Kendall and Pettitt tests.

\begin{tabular}{|c|c|c|c|c|c|}
\hline \multirow{2}{*}{ Catchment $^{\mathrm{a}}$} & \multicolumn{2}{|c|}{ Annual streamflow } & \multirow{2}{*}{$\begin{array}{r}\text { Slope }(\beta)^{\mathrm{b}} \\
\left(\mathrm{m}^{3} \mathrm{~km}^{-2} \mathrm{~mm}^{-1} \mathrm{a}^{-1}\right)\end{array}$} & \multicolumn{2}{|c|}{ Change point } \\
\hline & Test $Z$ & Significance & & Year & Significance \\
\hline Kuye $^{\mathrm{T}}$ & -5.59 & $* * *$ & -3.671 & 1981 & $* * *$ \\
\hline Tuwei ${ }^{\mathrm{T}}$ & -4.73 & $* * *$ & -2.871 & 1983 & $* * *$ \\
\hline Jialu $^{\mathrm{T}}$ & -7.24 & $* * *$ & -3.613 & 1982 & $* * *$ \\
\hline Qingjian $^{\mathrm{L}}$ & 0.13 & ns & 0.054 & - & - \\
\hline Yanhe $^{\mathrm{L}}$ & -0.47 & ns & -0.071 & - & - \\
\hline Yunyan $^{\mathrm{R}}$ & -2.53 & $*$ & -0.346 & 1995 & $* * *$ \\
\hline Shiwang ${ }^{R}$ & -4.13 & $* * *$ & -0.994 & 1988 & $* * *$ \\
\hline
\end{tabular}

a The superscripts in this column mean the locations of the study catchments. "T" means the transition zone from the sandy area to the loess hilly-gully area; "L", the loess hilly-gully area; and "R", the rocky mountain area. Some of following tables have the same marks. ${ }^{b}$ The unit is essentially dimensionless and the value in the column means 1000 times change rate of the runoff coefficient in catchment. Symbols "**”, “**” and "****” indicate significance levels of $0.05,0.01$, and 0.001 , respectively. "ns" indicates that significance level exceeds 0.05 .

in 1995 and 1988, respectively. The reason for the different change points is probably related to the time when the cumulative area for soil conservation measures in the catchments reached about $15 \%$. Results from Ran et al. (2000), Yao et al. (2004) and Xu and Sun (2006) implied that such a percentage of the area for soil conservation measures can significantly affect hydrological cycling and sediment retention or transportation in a catchment.

According to the change points for the five catchments and in consideration of the implementation of the "Grain for Green" project after 1999, the whole time period for streamflow data is divided into three periods: period 1 pre-change point year period, abbreviated to ( $\mathrm{P} 1)$; period 2 post-change period from pre-change point year to 1999, (P2); and period 3 "Grain for Green" period from 2000 to 2005, (P3). Monthly flow duration curves were derived and relative changes of streamflow at high (5\%), median $(50 \%)$ and low (95\%) percentiles in $\mathrm{P} 2$ and $\mathrm{P} 3$ as compared to $\mathrm{P} 1$ are listed in Table 4.

From Table 4, relative changes of streamflow were negative except for the two loess hilly-gully catchments, i.e., the Qinjian and Yanhe catchments. Change degrees, whenever in $\mathrm{P} 2$ or P3, were higher in the three transition zone catchments than those in the two rocky mountain catchments.

Change degrees of streamflow in the transition zone catchments were not only greater in $\mathrm{P} 3$ than those in $\mathrm{P} 2$, but also much greater than those in the rocky mountain catchments in P3. Average relative changes for the three transition zone catchments in $\mathrm{P} 3$ reached $72.5 \%, 58.4 \%$, and $57.3 \%$ at the high (5\%), median (50\%), and low (95\%) percentile flows, respectively. Moreover, average relative changes for the two rocky mountain catchments in P3 were $46.1 \%, 48.3 \%$, and $50.4 \%$ at the same percentiles, respectively. That means that the implementation of soil conservation measures exerted greater effects on the transition zone catchments than the rocky mountain catchments, especially in P3 when the "Grain for Green" project was implemented.
Change degrees were much weaker for the two loess hillygully catchments, i.e. ,the Qingjian and Yanhe catchments. The result is consistent with the trend detection for the five catchments.

\subsection{Trends, change points and relative changes for annual sediment load}

Like annual streamflow, annual sediment load in the five catchments except the two loess hilly-gully catchments showed statistically significant decreasing trends and change points (Table 5). The average change rate of annual sediment load in the three transition zone catchments was $-0.5547 \mathrm{t} \mathrm{km}^{-2} \mathrm{~mm}^{-1} \mathrm{a}^{-1}$, and in the two rocky mountain catchments, only $-0.0540 \mathrm{t} \mathrm{km}^{-2} \mathrm{~mm}^{-1} \mathrm{a}^{-1}$. Clearly, the average change rate for the former was nearly 10 times that for the latter.

Change points of annual sediment load were detected by the Pettitt test and the sequential Mann-Kendall test, and the results were generally consistent with each other except for the Kuyehe and Tuweihe Rivers. As compared with the original data series of the catchments, change points detected by the Pettitt test were considered to be rational, as shown in Table 5. It is clear that change points of annual sediment load also occurred earlier in the three transition zone catchments, from 1977 to 1979 , Whereas change points in the two rocky mountain catchments occurred later, both in $1982(\mathrm{Ta}-$ ble 5). Compared to Table 3, change points of annual sediment load in the five catchments were close to those of annual streamflow except for in the Yunyan catchment, which implies that the effects of controlling soil erosion and sediment yield in these catchments have been achieved through the surface runoff reduction by soil conservation measures. To investigate relative changes in annual sediment load in all the seven catchments, the three periods are identified for the sediment load data using the same period division criteria as those for annual streamflow (Table 6). 
Table 4. The relative changes in high, median, and low flow regimes in period 2 and 3 compared to period 1 for the seven catchments.

\begin{tabular}{|c|c|c|c|c|c|c|c|c|c|c|c|c|c|c|}
\hline \multirow{2}{*}{ Catchment $^{\mathrm{a}}$} & \multicolumn{2}{|c|}{ Kuye $^{T}$} & \multicolumn{2}{|c|}{ Tuwei $^{\mathrm{T}}$} & \multicolumn{2}{|c|}{ Jialu $^{\mathrm{T}}$} & \multicolumn{2}{|c|}{ Qingjian $^{\mathrm{L}, \mathrm{b}}$} & \multicolumn{2}{|c|}{ Yanhe $^{\mathrm{L}, \mathrm{b}}$} & \multicolumn{2}{|c|}{ Yunyan $^{\mathrm{R}}$} & \multicolumn{2}{|c|}{ Shiwang ${ }^{R}$} \\
\hline & $\mathrm{P} 2$ & P3 & $\mathrm{P} 2$ & P3 & $\mathrm{P} 2$ & P3 & $\mathrm{P} 2$ & P3 & $\mathrm{P} 2$ & P3 & $\mathrm{P} 2$ & P3 & $\mathrm{P} 2$ & P3 \\
\hline$\Delta Q_{5}(\%)$ & -35.8 & -76.0 & -43.7 & -59.2 & -47.4 & -82.3 & -6.8 & -27.3 & -11.0 & -28.0 & -38.8 & -51.6 & -46.2 & -40.6 \\
\hline$\Delta Q_{50}(\%)$ & -43.6 & -65.7 & -23.3 & -40.3 & -42.3 & -69.2 & 13.8 & -15.8 & 13.0 & -17.3 & -28.4 & -44.2 & -37.8 & -52.3 \\
\hline$\Delta Q_{95}(\%)$ & -96.1 & -64.9 & -16.2 & -27.0 & -37.3 & -80.1 & -63.9 & 23.0 & 42.4 & 1.0 & -0.1 & -46.0 & -23.2 & -54.8 \\
\hline
\end{tabular}

a The meaning of the superscripts in this row is the same as those in Table 3. ${ }^{\mathrm{b}}$ The change point years of 1980 and 1999 are given both for Qingjian and Yanhe catchments referring to other catchments.

Table 5. Trends of the annual sediment load and change points by the Mann-Kendall and Pettitt tests.

\begin{tabular}{|c|c|c|c|c|c|}
\hline \multirow{2}{*}{ Catchment $^{\mathrm{a}}$} & \multicolumn{2}{|c|}{ Annual sediment load } & \multirow{2}{*}{$\begin{array}{r}\text { Sen's slope }(\beta) \\
\left(\mathrm{t} \mathrm{km}^{-2} \mathrm{~mm}^{-1} \mathrm{a}^{-1}\right)\end{array}$} & \multicolumn{2}{|c|}{ Change point } \\
\hline & Test $Z$ & Significance & & Year $^{\mathrm{b}}$ & Significance \\
\hline Kuye $^{T}$ & -3.75 & $* * *$ & -0.552 & 1979 (1981) & $* *$ \\
\hline Tuwei $^{\mathrm{T}}$ & -4.38 & $* * *$ & -0.298 & $1978(1983)$ & $* * *$ \\
\hline Jialu $^{\mathrm{T}}$ & -4.85 & $* * *$ & -0.814 & 1977 (1982) & $* * *$ \\
\hline Qingjian $^{\mathrm{L}}$ & -1.32 & $\mathrm{~ns}$ & -0.194 & - & - \\
\hline Yanhe $\mathrm{L}^{\mathrm{L}}$ & -1.86 & ns & -0.150 & - & - \\
\hline Yunyan $^{\mathrm{R}}$ & -2.50 & $*$ & -0.053 & $1982(1995)$ & $*$ \\
\hline Shiwang ${ }^{R}$ & -5.45 & $* * *$ & -0.055 & $1982(1988)$ & $* * *$ \\
\hline
\end{tabular}

${ }^{a}$ The meaning of the superscripts in this column is the same as that in Table 3. ${ }^{b}$ The years in bracket in the column mean the change points for the annual streamflow in the catchments. Symbols "**, “**” and "***" indicate significance levels of $0.05,0.01$, and 0.001 . "ns" indicates that significance level exceeds 0.05 .

Table 6 shows that compared to P1, relative changes of sediment load in all the seven catchments were negative at the high $(5 \%)$, median $(50 \%)$, and low $(95 \%)$ percentiles of sediment transport regime in the two latter periods. Days of zero sediment load increased in all the catchments, including the two loess hilly-gully catchments.

For the three transition zone catchments, average relative changes at the high (5\%), median (50\%) and low (95\%) percentile sediment load in P2 were $56.0 \%, 60.2 \%$, and $33.5 \%$ and in $\mathrm{P} 3$ were $93.7 \%, 88.6 \%$, and $71.8 \%$, respectively. There were considerable differences in the relative change between the two periods. For the two rocky mountain catchments, average relative change at high sediment load was $58.9 \%$ in $\mathrm{P} 2$ and $78.4 \%$ in $\mathrm{P} 3$. The result indicates significant effects of soil conservation measures and the "Grain for Green" project on sediment transportation in the study area. However, the effect of "Grain for Green" project implementation is much greater than that of soil conservation measures due to the continuity in the implementation process.

From above two sections, change degrees of annual sediment load were detected to be much greater than those of annual streamflow in catchments.

\subsection{Dynamic relation of streamflow and sediment load in the catchments}

Change points of annual sediment load in the seven catchments (Table 5) are referred to identifying the periods and analyze the dynamic relation of streamflow to sediment load.
Figure 3 shows a set of scatter diagrams illustrating the relationship between monthly sediment load and monthly streamflow in the three periods in the seven catchments. Simple linear regression equations are presented simultaneously. Streamflow and sediment load were showed as X- and Yaxis variables in Fig. 3, respectively. Because no data were recorded in some months in some catchments, the monthly data of sediment load and streamflow in the flood season from May to October were used in the study, so as to make the results comparable.

Before analysis of the trend and change of the coefficient of equation, the structure of linear regression between streamflow and sediment load was tested using the Chow test to see if there was a statistical difference in the relationship between three periods in each catchment. Chow (1960) constructed the $\mathrm{F}$ test to detect the presence of a structural break and is commonly used in time series analysis. The results showed that there was a statistically significant difference with $p<0.05$ in relationship between streamflow and sediment load among periods in six catchments except for the Yunyan, one of the rocky mountain catchments. The result was basically consistent with the annual trend test in Tables 3 and 5, but the disagreement between the annual trend and monthly relationship in the Qingjian, Yanhe and Yunyan catchments was probably due to the hydrological regime in monthly scale, which greatly affected the relationship.

The range of the scattered distributions of monthly sediment load against monthly streamflow in the three transition 


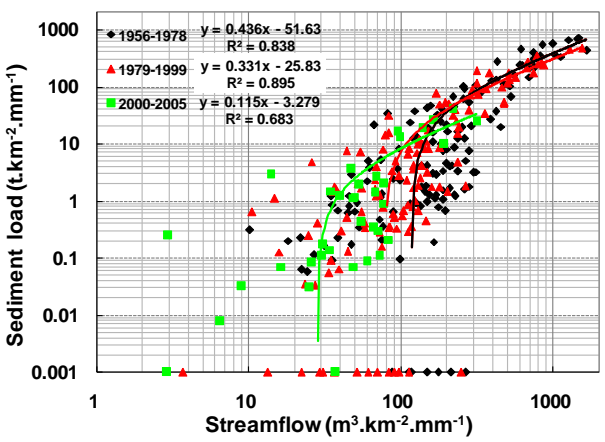

(a) Kuye catchment

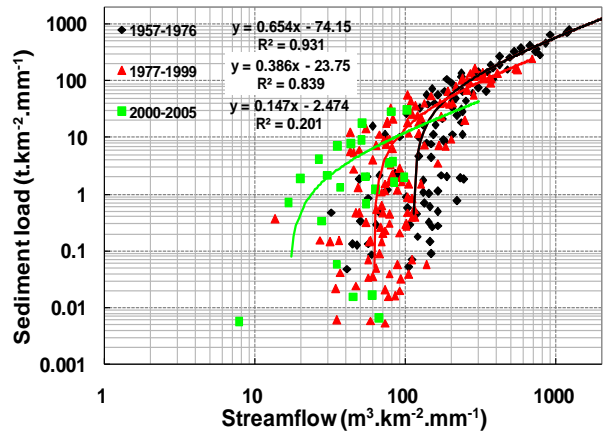

(c) Jialu catchment

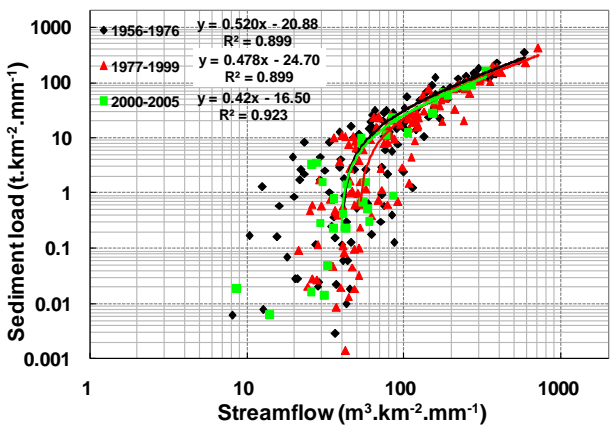

(e) Yanhe catchment

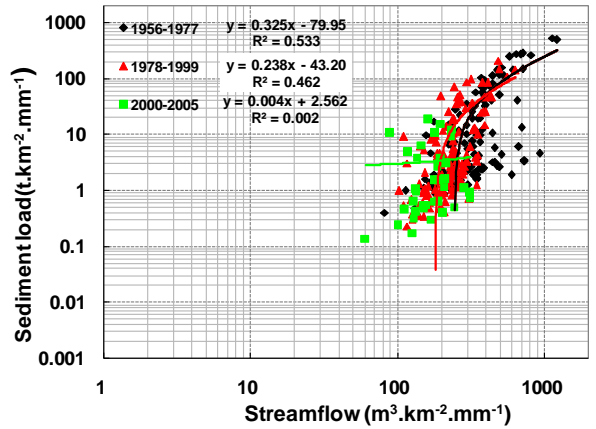

(b) Tuwei catchment

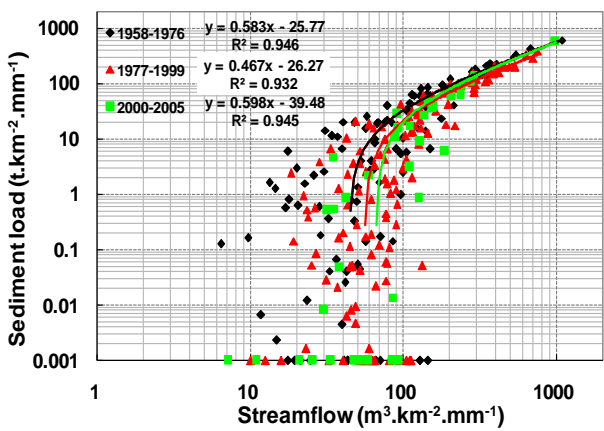

(d) Qingjian catchment

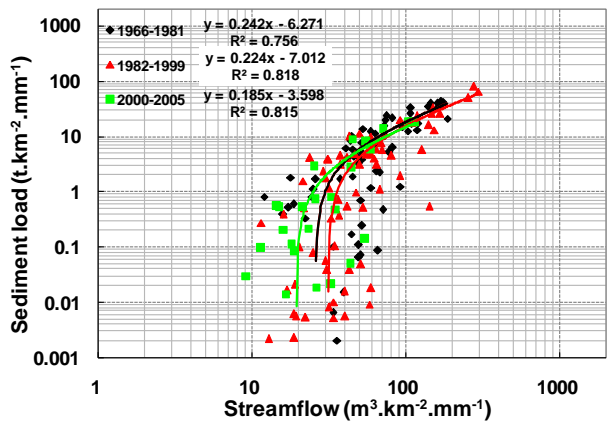

(f) Yunyan catchment

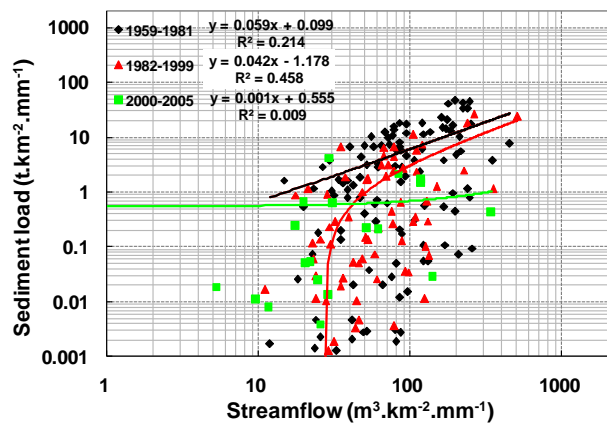

(g) Shiwang catchment

Fig. 3. The scattered distributions and simple linear regressions for monthly standardized streamflow and standardized sediment load from May to October in three periods in seven catchments. Streamflow is with unit of $\mathrm{m}^{3} \mathrm{~km}^{-2} \mathrm{~mm}^{-2}$, and sediment load, $\mathrm{tkm}^{-2} \mathrm{~mm}{ }^{-1}$. It is $\log$ transition both in X- and Y-axis. Plots (a), (b) and (c) represent the scattered distribution for the three transition zone catchments; plots (d) and (e), for the two loess hilly-gully catchments; and plots (f) and (g), for the two rocky mountain catchments. 
Table 6. The relative changes in high (5\%), median (50\%), and low (95\%) of sediment load regimes in the P2 and P3 for the seven catchments, as compared to the P1.

\begin{tabular}{|c|c|c|c|c|c|c|c|c|c|c|c|c|c|c|}
\hline \multirow{2}{*}{ Catchment $^{\mathrm{a}}$} & \multicolumn{2}{|c|}{ Kuye $^{T}$} & \multicolumn{2}{|c|}{ Tuwei $^{\mathrm{T}}$} & \multicolumn{2}{|c|}{ Jialu $^{\mathrm{T}}$} & \multicolumn{2}{|c|}{ Qingjian $^{\mathrm{L}, \mathrm{b}}$} & \multicolumn{2}{|c|}{ Yanhe $e^{\mathrm{L}, \mathrm{b}}$} & \multicolumn{2}{|c|}{ Yunyan $^{\mathrm{R}}$} & \multicolumn{2}{|c|}{ Shiwang $\mathrm{R}$} \\
\hline & $\mathrm{P} 2$ & P3 & $\mathrm{P} 2$ & P3 & $\mathrm{P} 2$ & P3 & $\mathrm{P} 2$ & P3 & $\mathrm{P} 2$ & P3 & $\mathrm{P} 2$ & P3 & $\mathrm{P} 2$ & P3 \\
\hline$\Delta S_{5}(\%)$ & -45.0 & -93.1 & -59.2 & -90.8 & -63.9 & -97.2 & -7.1 & -47.3 & -32.5 & -49.0 & -40.0 & -63.3 & -77.8 & -93.5 \\
\hline$\Delta S_{50}(\%)$ & -52.6 & -89.4 & -36.0 & -76.3 & -91.9 & -100 & -17.0 & -100 & -100 & -100 & - & - & - & - \\
\hline$\Delta S_{95}(\%)$ & -28.3 & -100 & -38.6 & -43.6 & - & - & - & - & - & - & - & - & - & - \\
\hline
\end{tabular}

a The mean of the superscripts in this row is the same with Table 3. ${ }^{\mathrm{b}}$ the change point years are given in 1977 and 1999 both for Qingiian and Yanhe catchments. P1, P2 and P3 have the same meaning as that in Table 4.

zone catchments is up to $\{2000,1000\}$, whereas only $\{500$, $100\}$ in the two rocky mountain catchments. Apparently, the former is much wider than the latter. The range of the scattered distribution in the two loess hilly-gully catchments lies in the middle. The factors, such as frequency of rainstorm, vegetation coverage, soil and hydrological geology, were supposed to determine the distribution scope of streamflow and sediment load in catchments (Ran et al., 2000).

The regression coefficients (with unit of $\mathrm{t} \mathrm{m}^{-3}$ ) can be considered as "sediment generation coefficients" because they may indicate the sediment generation capacity in the catchments. Figure 3 shows that the linear regression coefficients, in general, are much higher in the transition zone catchments and the loess hilly-gully catchments than those in the rocky mountain catchments. The average coefficients in P1, P2 and $\mathrm{P} 3$ are $0.4723,0.3164$ and 0.0891 in the three transition zone catchments and $0.5519,0.4728$ and 0.5093 in the two loess hilly-gully catchments, while they are only $0.1513,0.1336$ and 0.0932 in the two rocky mountain catchments. This indicates that as for per unit of streamflow, the catchments located in the transition zone and loess hilly-gully area had a stronger capacity to generate and transport sediment than the catchments in the rocky mountain area. The reason is apparently related to the high vegetation coverage in the rocky mountain area catchments, as shown in Table 1.

In consideration of standardization of streamflow and sediment load data with precipitation and controlling area, human activities such as soil conservation measures from the 1970s to 1980s and the "Grain for Green" project after 1999 were expected to make the sediment generation capacity in the catchments to be increasingly negative trends period by period, except for the two loess hilly-gully catchments (Table 7). Compared to $\mathrm{P} 1$, the average reduction rate of linear regression coefficients in $\mathrm{P} 2$ was $31.2 \%$ in the transition zone catchments and only $18.0 \%$ in the rocky mountain catchments, but in P3, it was up to $83.2 \%$ and $60.8 \%$, correspondingly. However, the negative trend was not evident in the loess hilly-gully catchments. Average reduction in P2 in all the seven catchments was $22.5 \%$ and in $\mathrm{P} 3,55.4 \%$ (Table 7).

From "preparation - Transportation" process of soil erosion (Asselman, 1999; Rovira and Batalla, 2006), the absolute value of a constant (with unit of $\mathrm{t} \mathrm{km}^{-2} \mathrm{~mm}^{-1}$ ) in the
Table 7. Reduction of the linear regression coefficients for the monthly sediment load and streamflow in the catchments $(\%)$.

\begin{tabular}{lrr}
\hline Catchment $^{*}$ & $(\mathrm{P} 2-\mathrm{P} 1) / \mathrm{P} 1$ & $(\mathrm{P} 3-\mathrm{P} 1) / \mathrm{P} 1$ \\
\hline Kuye $^{\mathrm{T}}$ & -25.8 & -73.5 \\
Tuwei $^{\mathrm{T}}$ & -26.9 & -98.7 \\
Jialu $^{\mathrm{T}}$ & -40.9 & -77.5 \\
Qingjian $^{\mathrm{L}}$ & -19.9 & 2.7 \\
Yanhe $^{\mathrm{L}}$ & -8.1 & -19.3 \\
Yunyan $^{\mathrm{R}}$ & -7.6 & -23.8 \\
Shiwang $^{\mathrm{R}}$ & -28.5 & -97.8 \\
\hline Average & -22.5 & -55.4 \\
\hline
\end{tabular}

* The superscripts in this column have the same meaning as that in Table 3.

linear regression equation for each of the catchments implies a status of existing in-channel sediment storage in a given period to some extent, which can demonstrate the "sediment generation capacity" in another way. In P1, much more sediment was stored in the three transition zone catchments than in the two loess hilly-gully catchments and the two rocky mountain catchments (Fig. 3). Correspondingly, average sediment storages were 68.6, 23.3 and 6.3, respectively. Generally, sediment storage in the catchments showed a decreasing trend period by period except the Qingjian catchment in the loess hilly-gully region. Compared to P1, soil conservation measures adopted in the 1970s and 1980s reduced sediment storage by $56.9 \%$ in the transition zone catchments and the "Grain for Green" project implementation further reduced it by $95.7 \%$.

From the point view of the equation, the streamflow volume at which sediment load equals zero may be understood as the situation in which a given catchment reaches its scour and silting balance (Fig. 3). The standardized streamflow volume at which the balance is needed for a catchment showed a decreasing trend with the shifted period in most of the catchments (Table 8). Especially in the three transition zone catchments, average reduction of the streamflow volume for the balance reached $38.0 \%$ in $\mathrm{P} 2$ and up to $80.6 \%$ in $\mathrm{P} 3$.

Compared to P1, the relationship between streamflow and sediment load generally became poor in the correlation coefficients from $\mathrm{P} 2$ to $\mathrm{P} 3$, especially in the transition zone 
Table 8. Comparison of the standardized streamflow volumes as the catchments reaches their scour and silting balances in the three periods.

\begin{tabular}{lrrr}
\hline Cachment* & P1 & P2 & P3 \\
\hline Kuye $^{\mathrm{T}}$ & 118.3 & 68.5 & 28.3 \\
Tuwei $^{\mathrm{T}}$ & 245.5 & 181.5 & - \\
Jialu $^{\mathrm{T}}$ & 113.3 & 61.4 & 16.8 \\
Qingjian $^{\mathrm{L}}$ & 44.2 & 56.3 & 66.0 \\
Yanhe $^{\mathrm{L}}$ & 40.1 & 51.6 & 39.3 \\
Yunyan $^{\mathrm{R}}$ & 25.8 & 31.2 & 19.5 \\
Shiwang $^{\mathrm{R}}$ & - & 27.7 & - \\
\hline
\end{tabular}

* The superscripts in this column have the same meaning as that in Table 3.

catchments as well as the Shiwang catchment, one of the rocky mountain catchments (Fig. 2a, b, c and g). On the Loess Plateau, human activities are recognized as the primary factor leading to the negative trends of streamflow and sediment load (Ran et al., 2000; Fu et al., 2004; Zhang et al., 2008; Rustomji et al., 2008; Yao et al., 2010). But human activities are wide ranging and some of them can potentially increase soil loss in the catchments (Ran et al., 2000; Wang and Fan, 2002).

The implementation of soil and water conservation was expected to control soil erosion and reduce sediment delivery to the Yellow River (Morgan, 1986; Chen et al., 1988). The "Grain for Green" project implemented since 1999 resulted in a considerable improvement of vegetation coverage on the Loess Plateau. However, sediment trapping dams built up in the 1970s and 1980s were easily damaged by heavy rainstorms (Zhang, 1995). The ratio of silted storage to the total storage of reservoir was up to $40 \%$ in the seven catchments (Xiong and Ding, 2004). The variability of sediment concentration in the catchments in P2 was closely related to the ruined sediment trapping dams and the release regime of reservoirs (Zhang, 1995; Ran et al., 2000). Moreover, rapid urbanization and extensive infrastructure construction were simultaneously proceeding in the region (Liu and Han, 2007), which usually produced a huge amount of sediment deposition and dreg on the river bed and probably led to a high concentration flow, even in a medium rain event (Xu, 2002).

In consideration of the standardization of the data by precipitation and catchment area, the decreasing/weakening trends of streamflow, sediment load, and their dynamic relation in the catchments were probably related to the characteristics of soil conservation measures adopted after the 1950s. One was the total controlled area by soil conservation measures; and the other was the allocation of soil conservation measures. Xu and Sun (2006) showed that a threshold existed in the area of soil and water conservation measures in reducing sediment yield in the Wudinghe River of the Loess Plateau. Yao et al. (2004) found that if the area controlled by dam-reservoirs in a catchment was less than $10 \%$ of the total area, the trend of sediment load reduction would not be significant. But the differences in the mechanisms of evaportranspiration and hydrologic cycle regime with different landforms and vegetation coverage degrees probably determined the intrinsic differences in the trends and change degrees of streamflow and sediment load as well as their relationship between catchments. Although a number of studies supported the viewpoint from a single factor, further research is definitely needed to find an integrated estimate for more catchments. The responses of streamflow and sediment load to the LUCC in the Qingjian and Yanhe catchments are different from those in other catchments. The result agrees with those from Dai and Yan (2002), Zhang et al. (2008), probably due to other kinds of human activities which aggravate soil erosion and increase sediment transportation in the catchment.

As a whole, the trends of three indices, i.e., regression equation coefficient, regression equation constant and the streamflow volume at which a scour and silting balance reached, are found to be increasingly negative with significant level in most of the catchments. The decreasing trends indicate that soil conservation measures and the "Grain for Green" project considerably weakened the sediment yield capacity and the dynamic relation of sediment load to streamflow in most of study catchments. On the other hand, it is the trend of streamflow and the weakening trend in relationship between streamflow and sediment load, which resulted in the negative trend of sediment yield in most catchments.

\section{Summary}

The impacts of soil conservation measures and the subsequent "Grain for Green" project on streamflow, sediment load, and their dynamic relations were examined for the seven catchments in the middle reaches of the Yellow River, China. The responses showed a great variety, but generally three types could be identified based on the spatial distribution of the catchments. Both annual streamflow and annual sediment load presented significant negative trends and change points in the three transition zone catchments and two rocky mountain catchments. In most of the cases, the decreasing change degrees of streamflow and sediment load in the three sandy transition zone catchments were greater than those in the two rocky mountain catchments. Change points detected in the sandy transition zone catchments were earlier than those in the rocky mountain catchments. Change degrees with the shifted periods in sediment load were much greater than those in streamflow, especially in the three sandy transition zone catchments. The implementation of soil conservation measures from the 1970 s to 1980 s reduced the sediment generation capability in the catchments by $22.5 \%$ and the subsequent "Grain for Green" project since 1999 further reduced it by $55.4 \%$. The combination of temporal change in streamflow and relationship between streamflow 
and sediment load resulted in a statistically significant trend in sediment load in catchments. The effects of the LUCC on the streamflow, sediment load and their relationships were much weaker in the two loess hilly-gully catchments, probably due to the other intensive human activities. The results imply that future catchment management plans for the CSHC should acknowledge the effects on the relationship between streamflow and sediment load by soil conservation measures and ecological restoration, and more sustainable measures should be considered to keep soil in site while not significantly affecting streamflow.

Acknowledgements. The work was supported by the National Natural Science Foundation of China (Grant No. 41101265) and the Knowledge Innovation Program of the Chinese Academy of Sciences (KZCX2-XB3-13) and the National Basic Research Program of China (973 Program) (2007CB407203). David Jupp and Yajun Guo are thanked for discussing the suitable relationship statistic method. And three anonymous reviewers are also thanked for their constructive comments.

Edited by: A. Wei

\section{References}

Asselman, N.: Suspended sediment dynamics in a large drainage basin: the river Rhine, Hydrol. Process., 13, 1437-1450, 1999.

Bi, H. X., Liu, B., Wu, J., Yun, L., Chen, Z. H., and Cui, Z. W.: Effects of precipitation and landuse on runoff during the past $50 \mathrm{yr}$ in a typical watershed in Loess Plateau, China, Int. J. Sediment Res., 24, 352-364, 2009.

Brown, A. E., Zhang, L., McMahon, A. W., and Vertessy, R. A.: A review of paired catchment studies for determing changes in water yield resulting from alterations in vegetation, J. Hydrol., 310, 28-61, 2005.

Castillo, V. M., Martinez-Mena, M., and Albaladejo, J.: Runoff and soil loss response to vegetation removal in a semiarid environment, Soil Sci. Soc. Am. J., 61, 1116-1121, 1997.

Chen, Y. Z., Jing, K., and Cai, Q. G. (Eds.): Modern soil erosion and its controlling on the Loess Plateau, Science Press, Beijing, 1988 (in Chinese).

Chow, G. C.: Tests of Equality Between Sets of Coefficients in Two Linear Regressions, Econometrica, 28, 591-605, doi:10.2307/1910133, 1960.

Colman, E. A. (Ed.): Vegetation and watershed management, The Ronald press company, New York, 1953.

Dai, M. Y. and Yan, L.: Analysis of Yanhe streamflow and sediment load, in: Researches on streamflow and sediment load in Yellow River, Volume I, edited by: Wang, G. and Fan, Z., Yellow River Water Conservancy Press, Zhengzhou, 623-643, 2002 (in Chinese).

Fu, G. B., Chen, S. L., Liu, C. M., and Shepard, D.: Hydro-climatic trends of the Yellow River Basin for the last 50 years, Climatic Change, 65, 149-178, 2004.

Fu, G. B., Charles, S. P., Viney, N. R., Chen, S. L., and Wu, J. Q.: Impacts of climate variability on stream-flow in the Yellow River, Hydrol. Process, 21, 3431-3439, 2007.
Gao, P., Mu, X.-M., Wang, F., and Li, R.: Changes in streamflow and sediment discharge and the response to human activities in the middle reaches of the Yellow River, Hydrol. Earth Syst. Sci., 15, 1-10, doi:10.5194/hess-15-1-2011, 2011.

Hamed, K. H. and Rao, A. R.: A modified Mann-Kendall trend test for autocorrelated data, J. Hydrol., 204, 182-196, 1998.

Hirsch, R. M., Slack, J. R., and Smith, R. A.: Techniques of trend analysis for monthly water quality data, Water Resour. Res., 18, 107-121, 1982.

Huang, M. B. and Zhang, L.: Hydrological responses to conservation practices in a catchment of the Loess Plateau, China, Hydrol. Process., 18, 1885-1898, 2004.

Kendall, M. G.: Rank Correlation Measures, Charles Griffin, London, 1975.

Kundzewicz, Z. W. and Robson, A. J.: Change detection in hydrological records - A review of the methodology, Hydrolog. Sci. J., 49, 7-17, 2004.

Li, L. J., Zhang, L., Wang, H., Wang, J., Yang, J. W., Jiang, D. J., Li, J. Y., and Qin, D. Y.: Assessing the impact of climate variability and human activities on stremflow from the Wuding River Basin in China, Hydrol. Process., 21, 3485-3491, 2004.

Liao, J. H., Xu, J. X., and Yang, Y. H.: Study of the spatial differentiation of hyperconcentrated flows frequency in the Loess Plateau, Adv. Water Sci., 19, 160-170, 2008 (in Chinese).

Liu, C. M. and Zhang, X. C.: Causal analysis on actual water flow reduction in the mainstream of the Yellow River, Acta Geogr. Sinica, 59, 323-330, 2004 (in Chinese).

Liu, C. M. and Zhong, J. R.: The effect of forest on stream flow in the Loess Plateau, Acta Geogr. Sinica., 33, 112-126, 1978 (in Chinese).

Liu, C. X. and Han, L. B.: Review of researches in vegetation restoration of freeway slopes, Acta Ecol. Sin., 27, 2090-2908, 2007 (in Chinese).

Liu, S. Y., Yu, X. X., Xin, Z. B., Li, Q. Y., Li, H. G., and Lei, F. Y.: Effects of land use change on runoff-sediment relationship at watershed in the loess hilly region, Prog. Geogr., 29, 565-571, 2010 (in Chinese).

Mann, H. B.: Non-parametric tests against trend, Econometrica, 13, 245-259, 1945.

McVicar, T. R., Li, L. T., Van Niel, T. G., Zhang, L., Li, R., Yang, Q. K., Zhang, X. P., Mu, X. M., Wen, Z. M., Liu, W. Z., Zhao, Y. A., Liu, Z. H., and Gao, P.: Developing a decision support tool for China's re-vegetation program: simulating regional impacts of afforestation on average annual streamflow in the Loess plateau, Forest Ecol. Manag., 251, 65-81, doi:10.1016/j.foreco.2007.06.025, 2007.

Morgan, R. P. C. (Ed.): Soil erosion and conservation, Longman Scientific and Technology, Harlow, Essex, England, 21-27/4547, 1986.

Mu, X. M., Zhang, L., McVicar, T. R., Chille, B. S., and Gao, P.:Estimating the impact of conservation measures on streamflow regime in catchments of the Loess Plateau, China, Hydrol. Process., 21, 2124-2134, 2007.

Pan, X. D., Li, Y., and Zhang, X. H.: The influence of the comprehensive treatment to streamflow and sediment load in the HekouLongmen region of Yellow River, Yellow Riv., 21, 13-15, 1999 (in Chinese).

Partal, T. and Kahya, E.: Trend analysis in Turkish precipitation data, Hydrol. Process., 20, 2011-2026, 2006. 
Pettitt, A.: A nonparametric approach to the change-point problem, Appl. Stat.-J. Roy. St. C, 28, 126-135, 1979.

Quinton, J. N., Edwards, G. M., and Morgan, R. P. C.: The influence of vegetation species and plant properties on runoff and soil erosion: results from a rainfall simulation study in south east Spain, Soil Use Manage., 13, 143-148, 1997.

Ran, D. C., Liu, L. W., and Zhao, L. Y. (Eds.): The soil conservation practices and streamflow and sediment load changes in the Hekou-Longmen region of middle reaches of Yellow River, Yellow River Water Conservancy Press, Zhengzhou, 2000 (in Chinese).

Rovira, A. and Batalla, R. J.: Temporal distribution of suspended sediment transport in a Mediterranean basin: The Lower Tordera (NE SPAIN), Geomorpholgy, 79, 58-71, 2006.

Rustomji, P., Zhang, X. P., Hairsinen, P. B., Zhang, L., and Zhao, J.: River sediment load and concentration responses to changes in hydrology and catchment management in the Loess Plateau region of China, Water Resour. Res., 44, W00A04, doi:10.1029/2007WR006656, 2008.

Sahin, V. and Hall, M. J.: The effects of afforestation and deforestation on water yields, J. Hydrol., 178, 293-309, 1996.

Sen, P. K.: Estimates of the regression coefficient based on Kendall's tau, J. Am. Stat. Assoc., 39, 1379-1389, 1968.

Sun, Y. P., Zhang, X. P., Xu, J. P., Ma, T. Y., and Lei, Y. N.: Temporal and spatial variation of NDVI of the water-wind erosion crisscross region in the Loess Plateau, J. Northwest Sci-Tech Univ. Agric. For.(Nat. SCI. ED), 40, 143-150, 2012 (in Chinese).

Tang, K. L. (Ed): The changes of erosion, runoff and sediment in the Yellow River, Science China Press, Beijing, China, 1993 (in Chinese).

Wan, L., Zhang, X. P., Ma, Q., Zhang, J. J., Liu, E. J., and Xie, M. L.: Spatiotemporal Trends of Precipitation on the Loess Plateau of China, in: International Congress on Modelling and Simulation, Perth, Australia, 12-16 December, 2011.

Wang, G. and Fan, Z. (Eds.): Researches on streamflow and sediment load in Yellow River, Volume I, Yellow River Water Conservancy Press, Zhengzhou, 623-643, 2002 (in Chinese).

Wang, H. J., Yang, Z. S., Saitoc, Y., Liu, J. P., Sun, X. X., and Wang, Y.: Stepwise decreases of the Huanghe (Yellow River) sediment load (1950-2005): Impacts of climate change and human activities, Global Planet. Change, 57, 331-354, 2007.

Wang, Y. Z. and Wu, X. D. (Eds.): The primary analysis of the relation of sediment load and climate in the up and middle reaches of the Yellow River for the past 70 years, in: The corpus of the study on environmental evolution and the streamflow and sediment transport rules in the Yellow River, edited by: Niu, Z. X., Geology Press, Beijing, 1993 (in Chinese).

World Meteorological Organization: Technical Regulations (WMO, No. 49), Secretariat of the World Meteorological Organization, Geneva, 1988.

Xin, Z. B., Xu, J. X., and Zheng, W.: Response of vegetation cover change to climate change and human activities in Loess Plateau, Sci. China Ser. D, 37, 1504-1514, 2007 (in Chinese).

Xiong, G. S. and Ding, L. Y.: The survey report of sediment deposition in the reservoirs of Yellow River Basin, Yellow Rover Conservancy Commission, Zhengzhou, Rep., 2004 (in Chinese).
$\mathrm{Xu}, \mathrm{J}$. X.: The impacts of human activity on hyperconcentrated flow in the middle reaches of Yellow River, Sci. Geogr. Sinica, 3, 294 299, 2002 (in Chinese).

$\mathrm{Xu}, \mathrm{J}$. X. and Sun, J.: Threshold phenomenon of sediment reduction beneficial from soil water conservation measures in the Wudinghe river, Adv. Water Sci., 17, 610-615, 2006 (in Chinese).

Xu, Z. X., Takeuchi, K., Ishidaira, H., and Li, J. Y.: Long-term trend analysis for precipitation in Asian Pacific FRIEND river basins, Hydrol. Process., 19, 3517-3532, 2005.

Yao, W. Y., Ru, Y. Y., and Kang, L. L.: Effect of flood retention and sediment reduction with different allocation system of water and soil conservation measures, J. Soil Water Conserv., 18, 28-31, 2004 (in Chinese).

Yao, W. Y., Li, Z. B., and Kang, L. L. (Eds.): The effects of controlling soil erosion on environment on the Loess Plateau, Science and Technology Press, Beijing, 2005 (in Chinese).

Yao, W. Y., Xu, J. H., and Ran, D. C. (Eds.): Analysis and evaluation of the water sand changing regime in catchments of Yellow River Basin, Yellow River Water Conservancy Press, Zhengzhou, 2010 (in Chinese).

Ye, Q. C. (Ed.): Researches on environmental changes of the Yellow River Basin and laws of water and sediment transportation, Shandong Science and Technology Press, Jinan, 1994 (in Chinese).

Yu, Y. M. (Ed): The trend study of soil conservation measures' benefit and streamflow and sediment load in the coarse sandy hilly area in the middle reaches of the Yellow River, Yellow River Water Conservancy Press, Zhengzhou, 1997 (in Chinese).

Zhang, L., Dawes, W., and Walker, G.: Response of mean annual evapotranspiration to vegetation changes at catchment scale, Water Resour. Res., 37, 701-708, 2001.

Zhang, S. L.: Investigation of the influence of the flood occurred in August 1994 on flow and sediment yield in Wuding River Basin, Yellow River, 5, 24-27, 1995 (in Chinese).

Zhang, S. L., Li, Z., and Zhao, W. L. (Eds.): The reason and developing trend of streamflow and sediment load in the Rich and Coarse Sandy region in the Yellow River, Yellow River Water Conservancy Press, Zhengzhou, 1998 (in Chinese).

Zhang, X. P., Zhang, L., Zhao, J., Rustomji, P., and Hairsine, P.: Responses of streamflow to changes in climate and land use/cover change in Loess Plateau, China, Water Resour. Res., 44, W00A07, doi:10.1029/2007WR006711, 2008.

Zheng, H. X., Zhang, L., Zhu, R. R., Liu, C. M., Sato, Y., and Fukushima, Y.: Responses of streamflow to climate and land surface change in the headwaters of the Yellow River Basin, Water Resour., Res., 45, W00A19, doi:10.1029/2007WR006665, 2009.

Zheng, M. G. and Cai, Q. G.: Effects of vegetation and other measures for soil and water conservation on runoff-sediment relationship in watershed scale, J. Water Conser., 38, 47-53, 2007 (in Chinese).

Zhu, X. M.: The impacts of vegetation on soil loss in the Loess region, Acta Pedol. Sinica, 8, 110-120, 1960 (in Chinese). 